\title{
Gavin Maxwell - The Lonely Naturalist
}

\section{Karen Lykke Syse}

University of Oslo

\begin{abstract}
Nature writers have had a strong influence on environmental ethics and history, and their anthropocentric positioning in the landscape combined with a bio-centric view of nature has become a key to understanding modern environmentalism. Using ethnological perspectives and cultural analysis as a starting point, the paper explores how the Scottish West Coast landscape was an important influence to the author Gavin Maxwell, and how his landscape perceptions trickled down to millions of readers through the popularity of his "Ring of Bright Water" trilogy. Maxwell's writing, following the Anglo-American naturalist ritual of seclusion, was influenced by his material surroundings. The landscape, culturally constructed as wilderness, was of vital importance to his narrative. Maxwell's life as well as those of the otters for whom he secured world wide support, were firmly anchored at Camusfeàrna, his Eden. Maxwell's role as an icon of cultural and natural heritage to present day environmentalists and nature lovers is explained through descriptions of the Gavin Maxwell visitor's centre, where pilgrims can visit Maxwell's shrine and explore the material relics of an important 20th Century naturalist. Finally, Maxwell's descriptions of his life have become an inspiration to many people escaping from urban areas to the solitude of the Scottish west coast. Some of these urban escapees have made their living filming, photographing and painting otters in an area where employment would otherwise be hard to find. Otters have become powerful totems and part of local discourse. What is the significance of these otters to people living in rural Scotland today?
\end{abstract}

Keywords: Gavin Maxwell - Environmentalism - Natural history - Nature writing - Animals - Totem - Otter - Landscape - Scotland - Ecology - Solitude.

While carrying out ethnographic fieldwork for a research project on the West coast of Scotland, I spent six months in a village of about 500 people in MidArgyll. I had rented a big and rather cold farmhouse, and moved over with my three children in January 2005. The children went to the local village school, and very quickly I found myself to be part of local village life. The houses 
in the village had mainly been taken over by people with second homes and incomers from England and urban Scotland. Only a handful of people living in the village had been there for more than a generation. As one of the English mothers told me, it was probably the most middle-class village in Argyll.

There were certain things I found surprising about living in this village. One was the otter-banter. Almost every day, the local otter would be mentioned. The children would be told to look out for the otter in the morning as the school bus drove past a loch were an otter lived. They would be on the look out on the way back from school too. Coming from Norway, I had expected polite conversation to be about the weather (of which there is a lot in Argyl1). However polite conversation very often was about the otter. I was wondering why everyone was so preoccupied with this otter. We have otters in Norway as well, but in my experience not many people, even in rural areas, talk about otter sightings. After getting to know the area better, I also discovered that there was a cinematographer in the village who made films about otters; there was also a photographer, who had otters as his favorite motive; moreover there was a resident artist who painted otters. In addition to this, quite a few other artists came to the village from other parts of Argyll or even all the way from Glasgow to draw or paint otters. One of them said to me that it would be interesting to keep count of how many people, whether through art or tourism, actually made their living out of the resident village otter.

Browsing through the bookshelves in my rented farmhouse, I found two well-thumbed books which caught my interest: Tarka the Otter by Henry Williamson (Williamson 1927) and Ring of Bright Water by Gavin Maxwell (Maxwell 1960). I quickly read them both, and as the two otter stories unfolded a new world of otter lore opened up. Locally, I noticed other interesting things related to the otter: the local laird's dog was called Mij, named after Gavin Maxwell's otter. Almost everyone had read Ring of Bright Water, and many people had seen the film and could point out or explain where it had been shot. I started reading more about Gavin Maxwell, and discovered that he had a visitors centre dedicated to his and his otters' memory.

Using Gavin Maxwell's Ring of Bright Water trilogy as a starting point, this article explores how Maxwell culturally constructed places out of what he defined as wilderness or untouched nature. Also it discusses how he used the landscape as a point of departure for dichotomies in his discourse. Moreover, the article seeks to explain why the landscape Maxwell played a part in protecting through his narratives became a place of pilgrimage to new generations of heritage-seeking environmentalists. Finally, I shall consider how the 
otter became such a powerful totem to environmentally-engaged locals and visitors to the West Coast of Scotland. By using ethnological methodology, analyzing the natural and cultural surroundings of a popular author such as Maxwell, and placing him in a naturalist tradition, it is my aim to describe, explain and understand Maxwell's influence on the environmentalist zeitgeist of today. Indeed, a good deal of the history of environmentalism can be understood by investigating the influential naturalists of the $20^{\text {th }}$ century, and their relations to the area they chose to live in. The actual landscape where they wrote their accounts of nature and naturalism is a significant part of their thinking.

\section{Gavin Maxwell's Biography}

Gavin Maxwell was a Scottish naturalist and author born in 1914 as the second son to Aymer Maxwell of Montreith. He died in 1969, only 55 years old. Maxwell's assistant Jimmy Watt wrote in 1999 that "Gavin Maxwell is remembered as someone who brought to many an awareness of the need to take care of our fellow inhabitants of this vulnerable earth" (Watt 2000:xiii). This statement suggests the degree to which Maxwell's reputation exceeds that ordinarily afforded an author.

In the book Ring of Bright Water Maxwell described how he initially brought the otter "Mij" from Iraq to the west coast of Scotland, and how Mij and the other otters in Maxwell's life fared around the farmhouse which he named "Camusfeàrna." Ring of Bright Water sold over a million copies and was in an amended form made into a film (1969) bearing the same title. After several exotic business ventures on the British Isles and abroad, Maxwell moved to Camusfeàrna or Sandaig (the first name for the place), an old farmhouse opposite Eilean Iarmain on a remote part of the Scottish mainland in 1949. He followed up Ring of Bright Water (Maxwell 1960) with The Rocks Remain (Maxwell 1963), and Raven Seek Thy Brother (Maxwell 1968) which was published the year before he died of cancer. After his home was destroyed by fire, he moved to the lighthouse cottage of Eilean Bàn, an island which he owned just off the coast of the Isle of Sky which at present supports a pier of the Skye Bridge built in the 1990s. Even with the cars passing thirty meters above it the island is now an otter sanctuary with a museum in memory of Gavin Maxwell and his otters. 


\section{Maxwell in the Anglo-American Naturalist Tradition}

Nature writing in prose has attained a distinct richness and continuity in the Anglo-American context during the last two centuries. Starting with Gilbert White's A Natural History of Selbourne in 1789, and moving up through the centuries and across the Atlantic, authors like Thoreau, Muir, Carson, Leopold and Coleridge, John Clare, Whitman, Hopkins and Dillard all belong to this tradition (Elder and Finch 1990:22). Maxwell can be linked to this naturalist tradition in more ways than one; however due to the scope of this paper emphasis will be placed on Maxwell's similarities to Henry Thoreau and Aldo Leopold. Both Maxwell and Leopold chose to write their books in the form of a diary, not unlike that of another diary - Walden. Both authors must have been influenced by Thoreau, and we know Maxwell had Walden sitting on his bookshelf.

Nature writers like Thoreau and Leopold have had a strong influence on environmental ethics and history, and their anthropocentric positioning in the landscape and bio-centric view of nature has become a key to understanding modern environmentalism (Anker 2003). Thoreau's narrated the happiness of his lonely life in the forest by Walden Pond: "I have, as it were, my own sun and moon and stars, and a little world all to myself." In 1949, ten years before Ring of Bright Water was published, Aldo Leopold conveyed the virtues of being isolated in nature in A Sand County Almanac: "There are degrees and kinds of solitude. An island in a lake has one kind; but lakes have boats, and there is always the chance that one might land to pay you a visit" (Leopold 1991:27). Ten years later Gavin Maxwell wrote: “.. to be quite alone where there are no human beings is sharply exhilarating; it is as though some pressure had suddenly been lifted, allowing an intense awareness of one's surroundings, a sharpening of the senses, and an intimate recognition of the teeming subhuman life around one" (Maxwell 2000:23).

Might isolation and loneliness be a prerequisite to become an influential naturalist? Thoreau, Leopold and Maxwell have followed a ritual of seclusion resulting in naturalist prose. This ritual is shared with other disciplines where nature is an important influence or end, both within eco-philosophy and nature conservation. ${ }^{1}$ In the quest for solitude all three authors describe a simple idyllic paradisiacal existence in harmony with nature. They also had a common yearning for a frugal existence with less focus on material things

1. See for instance the Seottish writer Hugh MacDiarmid, Conversationalists such as Muir and Fraser Darling, and eco-philosophers such as Niess. 
allowing them to focus on one of the truest values in life: conserving nature. Thoreau built his shack at Walden Pond with his own hands, using second hand windows and timber (Thoreau, 1894:78-79). Aldo Leopold's farmhouse was a run-down old place which he and his family restored, and which became "a week-end refuge from too much modernity" (Leopold 1991:viii). Gavin Maxwell describes his farmhouse at Camusfeàrna like this: "There was not one stick of furniture in the house; there was no water and no lighting, and the air inside struck me as a mortuary, but to me it was Xanadu" (Maxwell 2000:14). The interior furnishings of Maxwell's home at Camusfeàrna were mainly built from old fish boxes that came floating ashore. "I knew that something to sit upon would present no problems, (...) stacks of fish boxes arranged to form seats and tables were the mainstay of Camusfeàrna in those early days, and even now, despite the present comfort of the house, they form the basis of much of it's furniture, though artifice and padding have done much to disguise their origin" (Ibid:14/15). All three authors seem to have had a strong need to distance themselves from modernity and urban lives, and to focus on the virtues of a simple life in the country using nature as a metaphor and symbol of their virtues. This ritual of seclusion mentioned above seems to start with a difficulty in conforming to ordinary societal frames of conduct, resulting in a desire to escape from urban life and modern society. After indulging in isolation and loneliness in the wilderness, they unearth peace and happiness. As peace and happiness cannot be explained by solitude, they look around see Nature in all her glory and go on to promote Nature, or being in Nature, as the answer to the problems of the world.

\section{The land or landscape as Maxwell's point of departure and return}

The Foreword to Ring of Bright Water serves as Maxwell's introduction to the story of Camusfearna and his life with otters on the West Coast of Scotland:

(...) these places are symbols. Symbols for me and for many, of freedom, whether it be from the prison of over-dense communities and the close confines of human relationships, from the less complex incarceration of office walls and hours, or simply freedom from the prison of adult life and an escape into the forgotten world of childhood, of the individual and of the race [ . . . . (Ibid:5) 
As he explains, he uses the place as a symbol. However the landscape is also both an argument and an explanation for the dichotomies of his narrative. The virginal wilderness of the West Coast landscape is compared to the corrupt urban and modern world. The land around Camusfeàrna is good, and brings him back to the unsoiled state of childhood. The urban culture and way of life from which he has escaped, is implicitly bad. It stands in sharp contrast to the simplicity and solitude of the West Coast of Scotland which has given Maxwell freedom from modernity, societal demands, and adult responsibilities. He was perhaps a Peter Pan like figure who felt at ease in the company of children. Indeed he enjoyed the company of young boys, and kept two young assistants, ${ }^{2}$ Terry Nutkins and Jimmy Watt. According to his old friend and biographer Richard Frere, "they were lusty and jubilant young men, of Viking stature and Nordic good looks, and were then at an age when everything at Camusfeàrna (...) was seen in boyhood's visionary gleam as a rough playground spiced with adventure and endeavor" (Frere and McEwan 1999:12). This rough playground was also part of Maxwell's understanding of the place. An element of his "visionary gleam" was the waterfall which in part frames the area surrounding his old farmhouse. He writes that "It is the waterfall, rather than the house, that has always seemed to me the soul of Camusfeàrna" (Maxwell 2000:42). The photographic plates in the book show pictures of his young assistant Jimmy Watt standing naked by the waterfall as well as the otter Mij playfully romping around in the stream below. Frere doesn't insinuate that an improper relationship between Maxwell and his assistants existed, although elsewhere he refers to his friend's latent homosexuality: "He was obviously very fond of the boy. Their relationship was more that of father and son than employer and servant" (Frere and McEwan 1976:19). Even if Maxwell's homosexuality was not realized in his relationship with the two boys, it might in part explain his problems with conforming to society. Homosexuality in post-war Britain was illegal and totally unaccepted by the public. This can in part clarify Maxwell's need to flee society, and also support the theory that seeking isolation, loneliness, and even affection from animals rather than ones fellow (and perhaps condemning) humans can be a starting point for environmental concerns. Society chooses to exclude one, so one excludes oneself from society and turns to Nature.

Maxwell emphasized the innocence of the land, and chose to place himself and his narrative within this virginal place. He took the image of the land as an innocent playground even further, when he wrote that places such as 
Camusfearna were symbols of the childhood of the human race. His Eden, in which life was good and nature still virginal, was if not untouched then at least unhampered by humankind's environmental sins. "Through extensive interaction with a place, people begin to define themselves in terms of their relationships with and residence in that place, to the extent that they cannot really express who they are without inevitably taking into account the setting which surrounds them as well" (Ryden 1993:76).

Maxwell culturally constructed a place out of land he defined as wilderness or untouched nature. By naming the place, the land is given cultural significance (Tilley 1994:19). Maxwell deliberately kept the true name of Camusfeàrna secret, something which probably triggered the public's curiosity and wish to discover where the "true" Camusfeàrna really was. Maxwell actually re-named a place which already had a name of its own, thus giving it a new identity. Camusfeàrna wasn't really untouched wilderness, of course, even if it had become so through Maxwell's narrative. Generations of hard-laboring farmers had lived there, but in a modern world it wasn't any longer feasible for ordinary people to live in such a place. Scraping a living out of the fairly barren and inhospitable land was hard, and the scenery 'wouldn't keep your belly filled', to paraphrase one Argyllshire farmer. For a wealthy gentleman explorer and naturalist "scraping" a living from his pen, however, it was possible to be coquette about living on a monotonous diet of whitebait (!) for two months due to problems of isolation and inadequate supplies.

It is the wildness of the landscape previous generations had tried to tame that Maxwell emphasizes. "The winds rage in from the Atlantic and the hail roars and batters on the windows and the iron roof, all hell let loose (...)" (Maxwell 2000:9). It is therefore a bit surprising that he simultaneously refers to Camusfeàrna as both "Wilderness" and "Eden." In England, the "pastoral landscape" is usually understood as tame and cultivated rather than wild. Perhaps Maxwell's Scottish roots brings him closer to American nature writers, and the "American pastoral" around wild nature (Buell 1995). Camusfeàrna was surrounded with what Maxwell defined as lovable but inhospitable wilderness, something which deterred uninvited people from visiting.

The historian Donald Worster explains how nature can be viewed in two contrasting ways: the Arcadian, based on Gilbert White's nature musings describing his "Selbourne" as a natural paradise, and the imperial, based on Linnaes' systematic, rational and anthropocentric approach to nature (Worster 1994:2). This duality seems to be merged in the American pastoral as well as in Maxwell's approach to his surroundings. His wild and pastoral, aestheti- 
cally pleasing paradise on earth seemed a safe haven from the demands of the outside world: "The landscape and the seascape that lay spread before me was of such beauty that I had no room for it all at once; my eye flickers from the house to the islands, from the white sands to the flat green pasture round the croft, from the wheeling gulls to the pale satin sea and on to the snow-topped Cuillins of Skye in the distance" (Maxwell 2000:11). His description of the house itself as wearing "...the secretive expression that is in some way akin to a young girl's face during her first pregnancy" (ibid:12) makes the reader wonder what kind of secrets Maxwell himself was pregnant with to anthropomorphize his material surroundings in this way.

Interestingly, Maxwell uses the terms Landscape, Seascape and Waterscape to describe his surroundings. This panoramic way of regarding nature has also become the perspective academics use as an objective way of analyzing and interpreting nature. Any place which can be described by an author, or framed by an artist, map, camera or chart, becomes a landscape. Research (Syse 2000, 2006 in prep) indicates that few farmers or people with a utilitarian relationship with the land use the term "landscape" unless they are talking to academics or landscape managers. "Land" is the word commonly used by the people who work in the terrain itself to describe it, although often re-defined or divided in terms such as hills and fields, bogs and woods. The word "land" seems to be used in a tactile, active manner.

Even if Maxwell was a Scotsman by birth, he was at first a stranger to Sandaig, which he reinvented as Camusfeàrna. The place he construed in the landscape surrounding Camusfeàrna, became his Eden and known to his readers through his interpretation and agency. Even if it is possible to draw a dichotomy between the physical land and the representational landscape, this does not necessarily make the land truer than the landscape. One could perhaps say that the two terms explain different values attached to the geographical area described. The environmental values Maxwell attached to Camusfeàrna can be understood and conveyed through his interpretation and narratives, making (the) place an anchor for these values.

\section{Maxwell and the west coast as Heritage}

The evolution of the landscape reflects a change in our way of experiencing it. With industrialization and urbanization, nature became a consumption landscape as well as a production landscape. Experiencing wild, virginal 
nature became one of the reasons for exploring nature (Frykman and Löfgren 1994:64). Many people wish to escape urban life, and the reasons for wanting to escape are manifold. The pace of the city, the noise and stress related to communication, housing prices, the quality of schooling . . . the list could go on and on. Even so, the majority of people in Britain still live in cities or suburbs. Maxwell's beautiful and evocative descriptions of his life at Camusfeàrna must have inspired many people escaping from urban areas to the solitude of the Scottish west coast. Probably few people would admit to having been influenced by Maxwell to move out of cities, but nevertheless, an environmental groundswell connecting man's alienation from nature with the possibility of a different life, must have started bubbling somewhere. Other influential nature writers of the $20^{\text {th }}$ century probably play an important part in the rise of an environmental awareness (or zeitgeist), but the particular phenomena of the recent urban colonization of the west coast of Scotland is indebted to Maxwell.

Maxwell's wonderful descriptions of the Scottish west coast landscape in his simple prose endeared him, his subject matter, and Nature in all its forms, to his many readers. Camusfeàrna became a dream worth hanging on to, an Eden representing as much to the readers as it did to the author himself. This is possibly why the very nature Maxwell played a part in protecting, through his narrative, became a Heritage centre, a place of pilgrimage to new generations of environmentalists and nature lovers. His great influence can perhaps be understood by going to the Bright water visitor's center where pilgrims can explore the solitude of the west coast. The visitors center provides guided tours of Maxwell's museum, a reconstruction of his $40 \mathrm{ft}$ living room with original artifacts and Teko the otter's memorial stone. The Eilean Ban centre's webpage is full of information, and promotes the visitors center in this way:

For those who respect and enjoy the peace and quiet of a nature haven, the keepers' cottages on Eilean Bàn are available to rent. This exclusive self-catering accommodation offers the chance for guests to spend time doing their own wildlife spotting on the island, although the warden is on hand to point out the various flora and fauna to look for. Guests can wander the clearly marked paths at their leisure, and the island makes a perfect base for exploring all that Skye and Lochalsh has to offer. (http://www.eileanban.org/maxwell.htm)

The author and yachtsman Iain Mitchell visited the visitors centre in 1996. He describes how he went ashore to explore the island after having anchored his boat. As Maxwell's house was demolished by a fire 1968, now all that is left is a slight bump in the turf and a large stone of remembrance, where 
Maxwell's ashes are buried. The memorial plaque is scattered with shells and stones placed there by pilgrims who have made the journey down the long and unmarked forestry road. Mitchell writes: "Some of the larger stones carried inscriptions roughly etched by hand. One ... typically said, 'to Gavin Maxwell, we miss you'. By the stream there is a memorial, to Edal, one of the otters killed in the house fire. 'Whatever joy she gave you, give back to nature' Maxwell had inscribed on the plaque - wording of course by Maxwell himself. That too was strewn with shells and stones. I had no idea this place was a shrine" (Mitchell 1999/2004:204).

Visitors can walk on the same beach and play around the same stream that Maxwell and his otters splashed about in. The fact that Maxwell and his otters are long dead and the house is burned to the ground doesn't deter visitors from exploring Maxwell's world, a place that if not quite a shrine has at the very least become an important bit of Scottish Heritage. Tourists can in a sense reconstruct a mental image of what was once there through Maxwell's narrative, which lives on. The historian David Loewenthal questions the ethics of the heritage industry, arguing that by reconstructing landscapes we have never known but merely wish we had known, we become alienated from the present (Lowenthal 1999:13). But following Aldo Leopold we might define a conservation ethic thus: "An ethic, ecologically, is a limitation of freedom of action in the struggle for existence" (Leopold 1991:238). Paradoxically, even if Maxwell fled from the humdrum of urban life and tried to avoid sociability while living, his grave is probably visited by more people every year than he ever welcomed while living at Camusfeàrna.

\section{The otter - totem ${ }^{3}$ and symbol of environmental awareness}

The British have a reputation for being very fond of animals. The Royal Society for the Prevention of Cruelty to Animals (RSPCA) was founded as early as 1824. Queen Victoria stated that "No country can be called civilized that does not provide proper care for animals." Yet it took another seventy

3. A totem is any natural or supernatural being or animal which watches over or assists a group of people, such as a family, clan or tribe (Merriam-Webster Online Dictionary [1] and Webster's New World College Dictionary, Fourth Edition). Totems support larger groups than the individual person. In kinship and descent, if the apical ancestor of a clan is nonhuman, it is called a totem. Normally this belief is accompanied by a totemic myth. (http://en.wikipedia.org/wiki/Totem) 
five years before the Royal Society for Prevention of Cruelty to Children was established in 1889. A similar trajectory can be found in the United States, where the first Federal law protecting animals against cruel or abusive treatment came in 1873, and the first case of an abused child was tried in 1875 using the Society for the Prevention of Cruelty to Animals to intervene, as the child's welfare could only be improved by defining her as an animal in need of protection! ${ }^{4}$ In both countries, the RSPCA/SPCA focused initially on cruelty to domestic animals, although during the latter part of the $20^{\text {th }}$ century this sentiment also transferred to wild animals like the otter.

Up to the end of the $20^{\text {th }}$ century, the otter was considered fair game. In 1945, there were seventeen otter hunts in Britain. Otter hunting involved a pack of otter hounds under a Master kennel Huntsman with the hunters following on foot (Matless, Merchant et al. 2005). However the main reasons for the historical and present decline in otters, according to the UK Biodiversity action plan is not hunting but rather pollution of watercourses especially by $\mathrm{PCBs}$, insufficient prey associated with poor water quality, impoverished bank side habitat features needed for breeding and resting, and incidental mortality primarily by road deaths and drowning in eel traps.

The decline of the otter, then, can be seen as the result of all the environmental maladies produced by modern society. Gavin Maxwell's Ring of Bright Water brought the otter to the surface, so to speak. His narratives, photographs and sketches about the otters Mij, Edal, Teko, Mossy and Monday shared Maxwell's hands-on knowledge of otters with more than a million readers. The film which followed brought the beautiful Scottish landscape and the tear-jerking tragic death of Mij to the eyes of yet new audiences. Maxwell conveyed the plight of the otter through his descriptions of Camusfeàrna: "The ways in which people understand and use different spaces and places influence their relationships with the various others (including animals) encountered there" (Holloway 2003:147). The nature of the otter and that of Maxwell's anthropomorphized otters in particular, parallels that of early man. Like our hands, an otter's front paws have long, finger-like extremities which can be used to juggle and manipulate tiny objects like marbles or matches. The otter uses tools like stones for instance to crack open shells. The otter's body-language and emotions can also be likened to those of a dog. Indeed, Mij became Gavin Maxwell's substitute for a dog: "While I was quite clear that I 
did not want to own another dog, and that Jonnie' $s^{5}$ death had in some sense ended an overlong chapter of nostalgia in my life, it was, I think, autumn and winter's days at Camusfeàrna that with their long hours of darkness made me crave for some animal life about the house" (Maxwell 2000:66). Mij even shared the privilege of Maxwell's bed: "Mij slept in my bed (by now, as I have said, he had abandoned the teddy-bear attitude and lay on his back under the bedclothes with his whickers tickling my ankles and his body at the crook of my knees) and would wake with bizarre punctuality at exactly twenty past eight in the morning." Mij wasn't only Gavin Maxwell's pet otter; he became the pet otter of a whole nation. Douglas Botting, Maxwell's biographer said "Gavin made his greatest impact through Ring of Bright Water, which marked the beginning of a groundswell of worldwide support for otter conservation that has continued to the present day. Gavin's contribution to saving the otter was immeasurable, and was probably the greatest achievement of his life" (Botting 1993). The groundswell Botting refers to, is reflected by the otter banter in the village referred to in the introduction of this paper. "Animals have a symbolic availability allowing them to be drawn upon in the construction of meaning" (Baker 1993:5). Otters have become powerful symbols or totems of the environmentally engaged people, and part of the local discourse in general. Perhaps one can say the otter is a symbol of people caring, not only about the charming doglike humanlike creature swimming about the waters but about the environment in general.

\section{Works Cited}

Anker, P. (2003). "The Philosopher's Cabin and the Household of Nature." Ethics, Place and Environment 6(2): 131-141.

Baker, S. (1993). Picturing the Beast: Animals, Identity, and Representation. Manchester; New York, Manchester University Press.

Botting, D. (1993). Gavin Maxwell: A Life. London, HarperCollins.

Buell, L. (1995). The Environmental Imagination: Thoreau, Nature Writing, and the Formation of American Culture. Cambridge, Mass.; London, Belknap Press of Harvard University Press.

Elder, J. and R. Finch (1990). The Norton Book of Nature Writing. New York, W.W. Norton. 
Frere, R. and R. McEwan (1976). Maxwell's Ghost: An Epilogue to Gavin Maxwell's Camusfearna. London, Gollancz.

- (1999). Maxwell's Ghost: An Epilogue to Gavin Maxwell's Camusfearna. Edinburgh, Birlinn Ltd.

Frykman, J. and O. Löfgren (1994). Det kultiverte mennesket. Oslo, Pax.

Holloway, L. (2003). "'What a Thing, Then, Is This Cow...': Positioning Domestic Livestock Animals in the Texts and Practices of Small-Scale 'Self-Sufficiency'." Society \& Animals 11(2): 145-165.

Leopold, A. S. (1991). A Sand County Almanac and Sketches Here and There. Illustrated by Charles W. Schwartz. Oxford University Press: New York.

Lowenthal, D. (1999). The Past is a Foreign Country. Cambridge, Cambridge University Press.

Matless, D., P. Merchant, et al. (2005). "Animal Landscapes: Otters and Wildfowl in England 1945-1970." Transactions of the Institute of British Geographers 30 (2): 191-205.

Maxwell, G. (1960). Ring of Bright Water. London, Longmans.

- (1963). The Rocks Remain. London, Longmans.

- (1968). Raven Seek Thy Brother. London \& Harlow, Longmans.

- (2000). The Ring of Bright Water Trilogy. London, Penguin.

Mitchell, I. (1999/2004). Isles of the West: A Hebridean Voyage. Edinburgh, Canongate.

Ryden, K. C. (1993). Mapping the Invisible Landscape : Folklore, Writing and the Sense of Place. Iowa City, University of Iowa Press.

Thoreau, H. D. (1989). Walden or Life in the Woods. Princeton, N.J., Princeton University Press.

Tilley, C. (1994). A Phenomenology of Landscape: Places, Paths and Monuments. Oxford, Berg.

Williamson, H. (1927). Tarka the Otter: His Joyful Water-life and Death in the Country of Two Rivers. London, G.P. Putnam's Sons.

Worster, D. (1994). Nature's Economy: A History of Ecological Ideas. Cambridge, Cambridge University Press. 